TECHNICAL TRANSACTIONS 6/2017

CZASOPISMO TECHNICZNE 6/2017

CIVIL ENGINEERING

DOI: $10.4467 / 2353737$ XCT.17.089.6565

Stanisław Duży (stanislaw.duzy@polsl.pl)

Grzegorz Dyduch

Wojciech Preidl

Grzegorz Stacha

Artur Czempas

Sandra Utko

Faculty of Mining and Geology, Silesian University of Technology

\title{
EVALUATION OF THE TECHNICAL CONDITION OF THE "FRYDERYK" ADIT IN TARNOWSKIE GÓRY FOR THE PURPOSE OF EVENTUAL REVITALIZATION
}

\author{
OCENA STANU TECHNICZNEGO OBUDOWY SZTOLNI „FRYDERYK” \\ W TARNOWSKICH GÓRACH POD KĄTEM JEJ DOCELOWEJ REWITALIZACJI
}

\begin{abstract}
The "Fryderyk" adit (renamed 'Kościuszko' after World War II) is the last adit built in the area of Tarnowskie Góry, and was supposed to provide drainage for the area of exploitation of the "Fryderyk" mine. After the shutdown of the mine, the adit gained an important role in the water management of the area. The water from nearby sources flows into the river Drama through the adit. The long period of the adit's existence and the processes occurring in its area have caused a progressive process of support degradation, which increases the danger of a loss of stability and a collapse of the roof. Allowing the collapse of the adit's roof may cause surface depressions. The article presents the research results that show an evaluation of the technical condition and safety degree of the support for future failure-free usage. A range of activities that are meant to stop the natural degradation of the end section of the adit has also been suggested.
\end{abstract}

Keywords: mining monuments, support, heading stability, surface deformation

\section{Streszczenie}

Sztolnia „Fryderyk” (po II wojnie światowej „Kościuszko”) jest ostatnią z wybudowanych sztolni w rejonie tarnogórskim i miała odwadniać rejony eksploatacji rud w obszarze kopalni „Fryderyk”. Po zamknięciu kopalni sztolnia spełnia ważną rolę w gospodarce wodnej rejonu. Spływa nią woda z okolicznych źródeł do rzeki Dramy. Długi okres istnienia sztolni i procesy zachodzące w jej otoczeniu spowodowaty postępujący proces degradacji obudowy powodujący wzrost zagrożenia utratą jej stateczności i wystąpienia zawału. Dopuszczenie do zawału sztolni może doprowadzić do powstania na powierzchni zapadlisk. W artykule przedstawiono wyniki badań obejmujących ocenę stanu technicznego i stopnia bezpieczeństwa obudowy pod kątem dalszego bezawaryjnego użytkowania wyrobiska. Zaproponowano również zakres działań mających na celu zahamowanie naturalnej degradacji końcowego jej odcinka.

Słowa kluczowe: zabytki górnicze, obudowa górnicza, stateczność wyrobisk, deformacja powierzchni 


\section{Introduction}

Execution of the works related to the revitalization of historic underground structures requires a consideration of three mutually interlocking issues, namely:

- historical assets of the heading and taking care to minimalize the impact of corrective actions on its final state,

- state of the rock mass in the vicinity of the heading, including the possibility of discontinuous deformations on the surface,

- the condition of the support in the analyzed heading, taking into account environmental factors affecting its state.

The proposed corrective measures to counter further degradation of the heading should be the least possible impact on its historical appearance and also stop the process of natural degradation of the heading.

This problem is illustrated with the example of the "Fryderyk" adit in Tarnowskie Góry. To solve the task based on the results of research, which assessed the properties of rocks and the rock mass in the vicinity of the heading, the technical parameters of the support had to be obtained and an analysis of its stability had to be performed. The analysis of the stability of the heading is based on the probabilistic analysis of structural elements taking into account the variability of the parameters characterizing the structure and the rock mass, the variability of the cross-sectional dimensions of the heading and of its support. A classification of the conditions for maintaining the stability of the heading on each of its segments was carried out on the probability of loss of stability. The analysis was the basis to determine the necessary actions that had to be taken in order to stop the degradation of the heading, taking into account natural, technical, economic and historical conditions.

\section{General characteristics of the "Fryderyk" adit}

Ore mining in the region of Garb Tarnogórski was conducted since the beginning of the sixteenth century and was continued intermittently until the 1930s. Mines in the area of Tarnowskie Góry managed the water threat in two ways: either by removing water with the use of various types of treadmills and pumps or by gravity drainage of the adit tunnels by the means of drainage systems. The first tunnels in this area were drilled at the beginning of the sixteenth century.

The "Fryderyk" (Kościuszko) adit (its historical name is Tiefe Friedrich Stollen, which means "deep tunnel Frederick") is the last of eight tunnels built in the area of Tarnowskie Góry. It transported water from the following ore mining fields: Sztolniowy, Miejski, Suchogórski and Bobrownicki, which belonged originally to the mine called "Fryderyk": After World War II, the name of the adit was changed to "Kościuszko".

The outlet tunnel is located in the valley of the Drama river, east of the village of Zbrosławice. The adit spreads for about $880 \mathrm{~m}$ to the west, joining with river Drama. The outlet part of the underground tunnel included a classical sandstone brick gate (Fig. 1). 


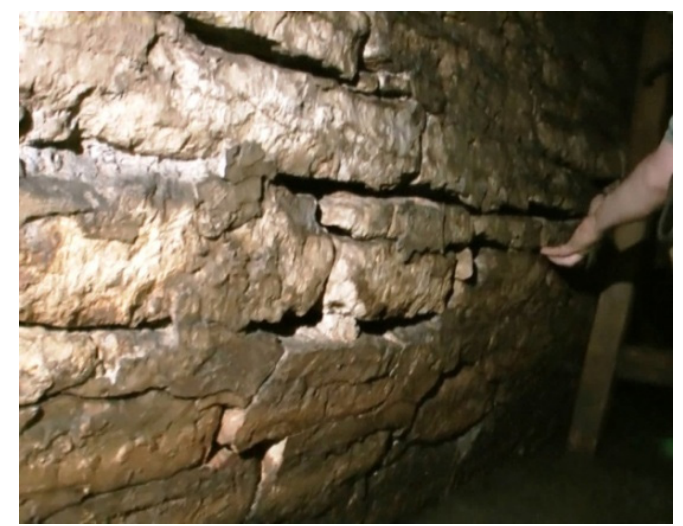

Fig. 1. Fryderyk” (“Kościuszko”) adit inlet portal (made 02.08.2016)

The total length of all parts of the „Fryderyk” adit is approx. $4568 \mathrm{~m}$, while the analysis includes $1275 \mathrm{~m}$ (Fig. 2).

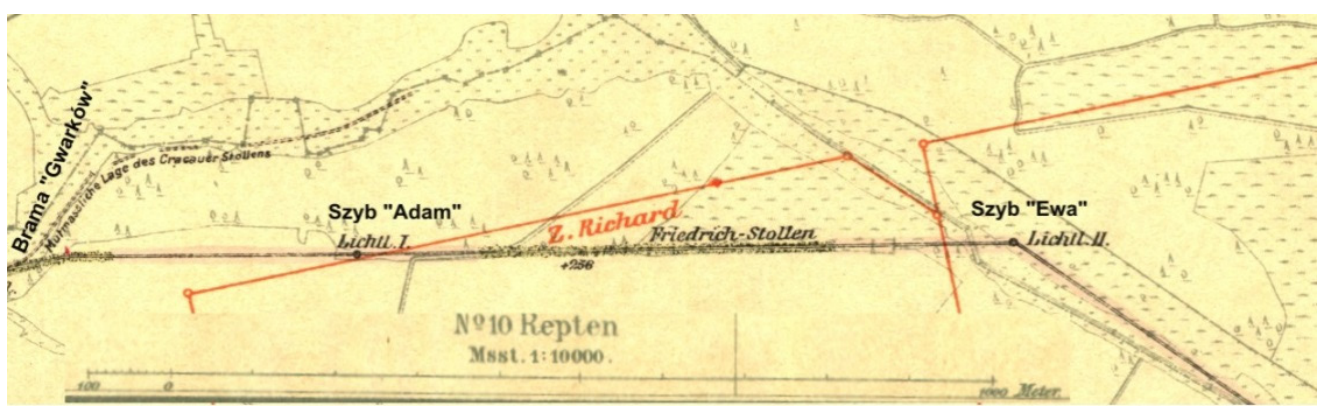

Fig. 2. The adit course, as based on the „Karte des Oberschlesischen Erzbergbaues” map from 1912 [12]

The entire length of the heading has a support made of arched, natural stone masonry (carbonate rocks). The roof with an arrow of $f=0.5 \mathrm{~m}$ is based on simple sidewalls with a height ranging from approx. $1.9 \mathrm{~m}$ to approx. $2.3 \mathrm{~m}$. The thickness of the support was measured at the sidewalls, in brickwork cavities, and was approx. $0.3 \mathrm{~m}$.

In places where preventive work was conducted as a result of failure, parts of the support were made from brick on concrete mortar and concrete. These enclosures were built in tunnels after 1945 and have no historical assets. The initial section of the tunnel with a length of about $110 \mathrm{~m}$, azimuth $77^{\circ}$, is made in a masonry stone case with hewn stone on lime mortar. The section of the tunnel that collapsed in August of 2008, at a length of about 3m, does not have a concrete structure, as it was reconstructed only with the use of wooden supports. At a distance of about 4 meters from the place where the roof collapsed, a concrete support was built. In 1962, a cave-in occurred in this place and was later secured with a concrete support laid behind the shoring. There are also traces of wooden shoring planks. In that section, the dimensions of the tunnel are: width of $1.75 \mathrm{~m}$ and a height of $2.75 \mathrm{~m}$. 


\section{Geological and mining characteristics in the aforementioned section of the adit}

The aforementioned section of the "Fryderyk" (Kościuszko) tunnel is located in the central part of Garb Tarnogórski.

The rock mass is permeable; therefore, numerous break-ins of water and quicksand occurred during the drilling of the heading. According to the available sources, the first $60 \mathrm{~m}$ of the tunnel were built using the opencast method. The overburden layer in this section has a thickness of 2 to 6 meters.

Along the adit, the tunnel can be divided into sections distinguishable as being made in the quaternary sediments and limestone (Fig. 3).

Quaternary deposits are developed in the form of layers of fine yellow and brown sand, light grey silt and clay.

Limestone lies underneath the quaternary sediments, with variable strength properties and different fracturing.

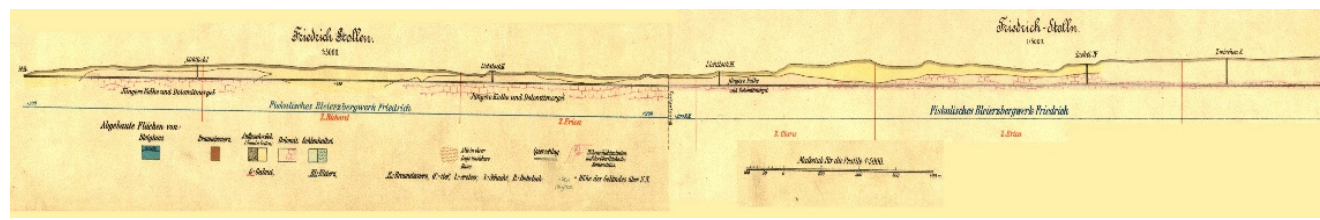

Fig. 3. The geological cross - section along "Fryderyk" adit, based on the „Karte des Oberschlesischen Erzbergbaues” [12]

\section{Evaluation of the technical condition of the support in the „Fryderyk” (Kościuszko) adit}

The macroscopic evaluation of the technical condition of the support showed that:

- along the entire length of the heading, the support is made of masonry vaulted natural stone. The arrow of the roof with $f=0.5 \mathrm{~m}$ is based on simple sidewalls with a height ranging from approx. $1.9 \mathrm{~m}$ to approx. $2.3 \mathrm{~m}$. The thickness of the support measured at the sidewalls is approx. $0.3 \mathrm{~m}$. Generally, the height of the support measured the water level is approx. $1.2 \mathrm{~m}$, and at the level of the heads of the sidewalls, it is approx. $1.3 \mathrm{~m}$. The height of the heading grows from approx. $2.4 \mathrm{~m}$ in the inlet to approx. $2.8 \mathrm{~m}$ at a distance of approx. $1000 \mathrm{~m}$. It was noted that, at short distances, the heading slightly changes its size, with the support expanding to approx. $1.75 \mathrm{~m}$ of height or reduces to approx. $1.9 \mathrm{~m}$ of height while narrowing to approx. $1.0 \mathrm{~m}$,

- it was found that damages to the support vary along the adit,

- within the distance of 0-45 m from the Miners' Gate, there are losses in brickwork and mortar in the joints, loosened parts of the support and its deformation. In this section, there is a damage zone with a collapsed part of the tunnel, which was rebuilt with a wooden support (Fig. 5), 
- the sections between $45-118 \mathrm{~m}, 126-143 \mathrm{~m}, 156-158 \mathrm{~m}, 632-739 \mathrm{~m}, 761-788 \mathrm{~m}$, 969-979 and 1149 to 1163 meters from the Miners' Gate show earlier repairs of the support through its partial replacement with a masonry brick or monolithic concrete support. There are also a lot of biological contaminants - roots piercing the support, washing of the mortar joints by old water leaks, loosened parts of the support and washing of the sidewalls of the support (Fig. 6),

- the sections of the tunnel between 118-126 m, 143-156 m, 158-632 m, 739-761 m, 788-969 m, 979-1149 and 1163 to 1268 meters from the Miners' Gate show small losses of the support material, infiltration of salt, small flows of water, etc., which currently do not threaten the stability of the heading (Fig. 7).

In order to determine the capacity of the support, material samples were taken from the wall. Petrographic studies showed that the rock from which the sample is made has carbonate origin: limestone with clear stratification planes. The cross-sections taken during sample cutting for strength testing showed horizontal slit aperture of about $0.1 \mathrm{~mm}$ filled with secondary mineral association with clearly dark yellow and rusty colours. Moreover, an individual focus of about $2-5 \mathrm{~mm}$ quartz grains is also visible (Fig. 4).
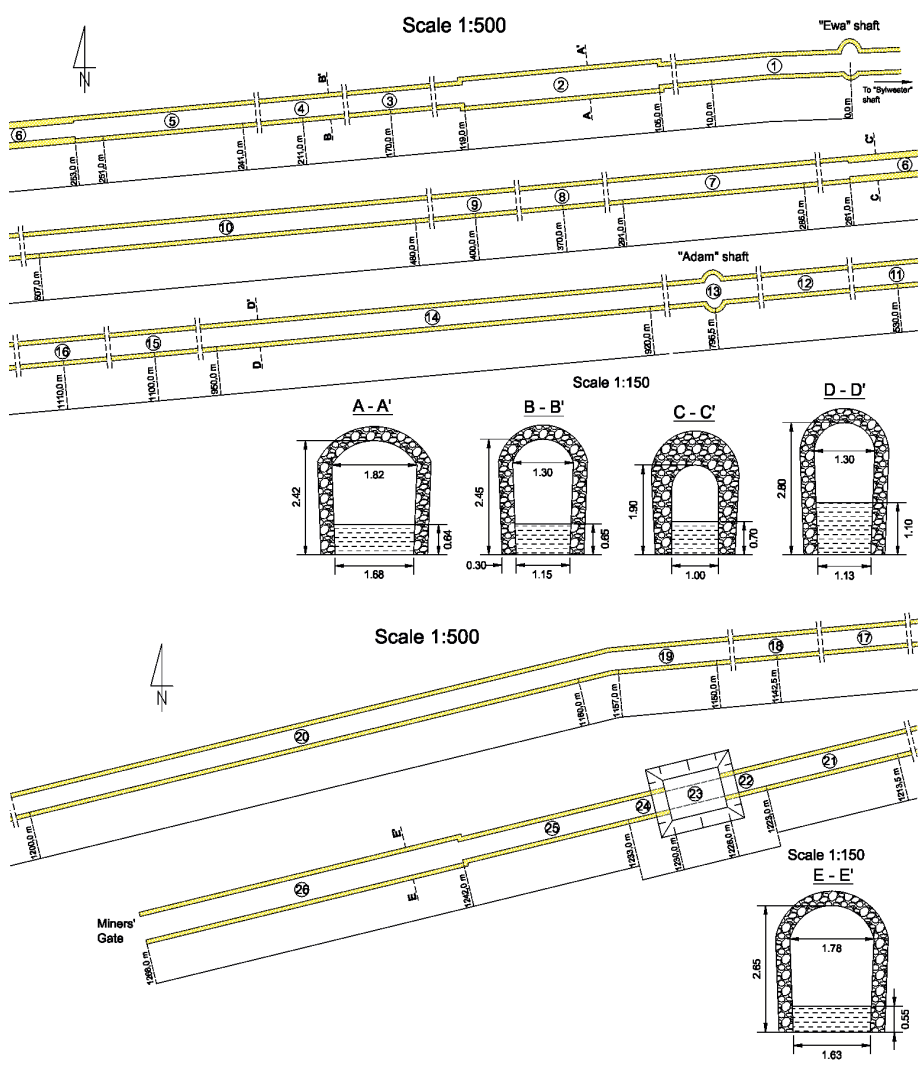

Fig. 4. The approximate location of characteristic points and damages of the support along the heading [10] 


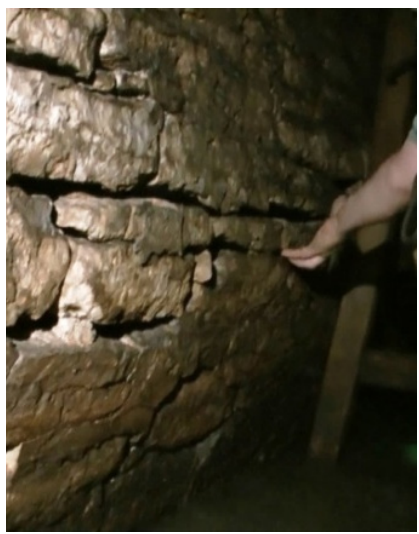

Fig. 5. View of "Fryderyk" adit in the area of point 25 on Fig. 4 [10]

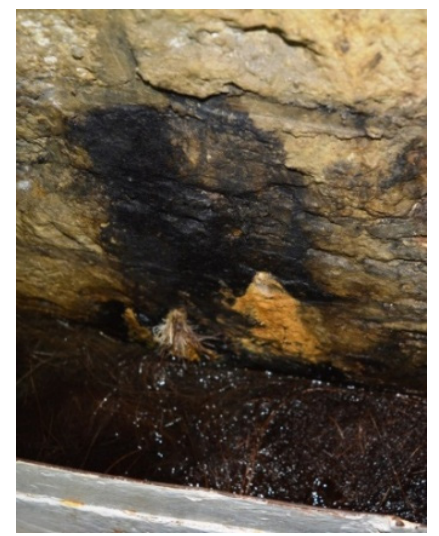

Fig. 6. View of "Fryderyk" adit in the area of point 20 on Fig. 4 [10]

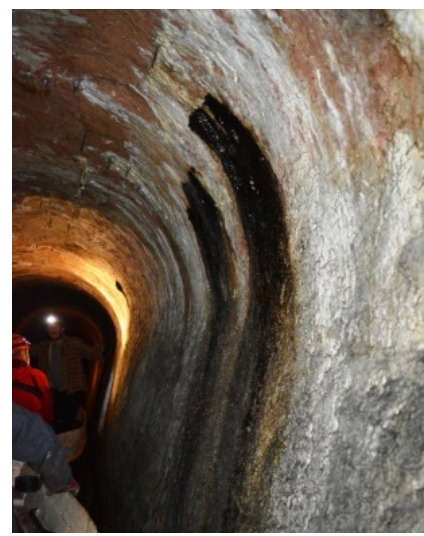

Fig. 7. View of "Fryderyk" adit in the area of point 9 on Fig. 4 [10]
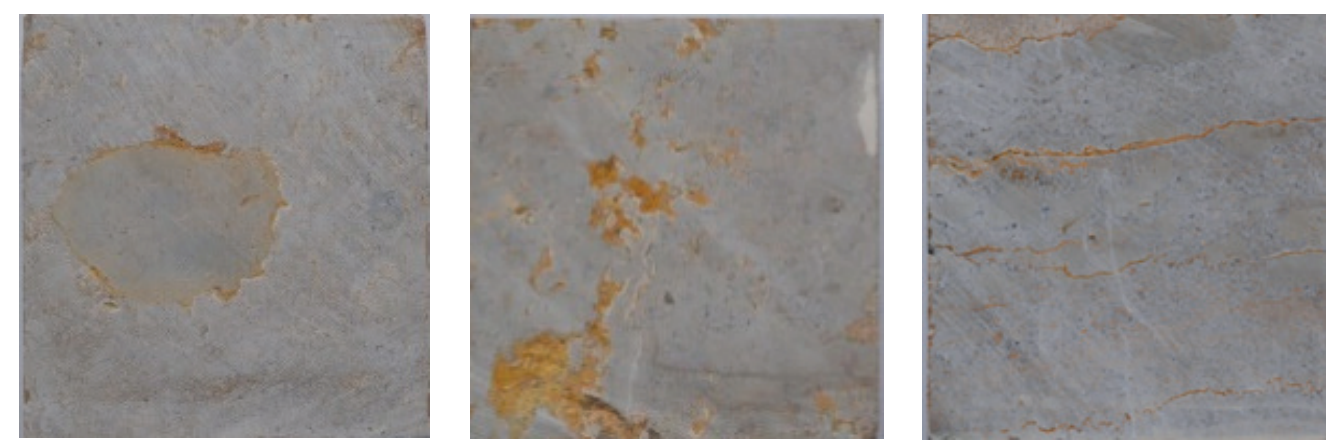

Fig. 8. Examples of sample cut surface views with visible gaps filled with a yellow-rust colored substance [10]

Limestone masonry samples taken from the support were used for strength tests. The study was conducted in accordance with PN-G-04303:1997. Test specimens were prepared in the shape of a cuboid with a square base having a side of $42 \mathrm{~mm}$ and a slenderness ratio equal to 1 and 2 to respect the limit of tolerance. Crosshead speed of samples was assumed to be the same as for strong rocks - equal to $1.0 \mathrm{MPa} / \mathrm{s}$.

Figures 9 and 10 show photographs of selected samples in the testing machine, taken prior to the commencement of the tests and after the destruction of the sample.

The design value of the compressive strength and the coefficient of variation for the test material was determined according to PN-B-03020:1981. Building land. Direct foundation of the building.

In the summary of the results of research strength of the support of the heading, it was found that:

- The average design value of the compressive strength of the tested support of the heading is $3.22 \mathrm{MPa}$, 
- The test proved the occurrence of local corrosion related mainly to places with water leaks behind the support; losses caused by corrosion did not usually exceed $10 \mathrm{~mm}$ and are not dangerous for the structure of the support,

- The excavation has numerous zones of heterogeneity within the structure of the support wall, related to losses of mortar in the joints, causing reduction of structural integrity, and thus decrease in its mechanical properties.

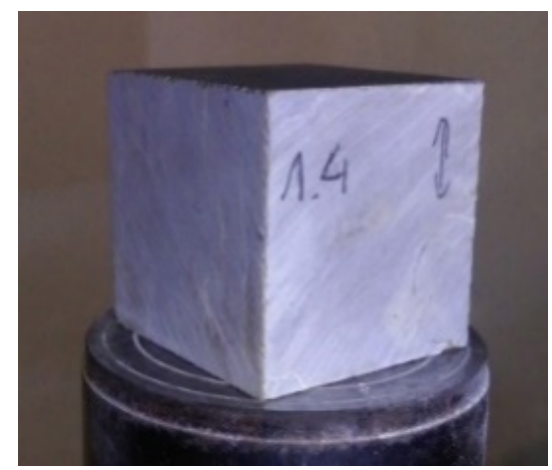

Fig. 9. View of pre-study sample in the universal testing machine $[10]$

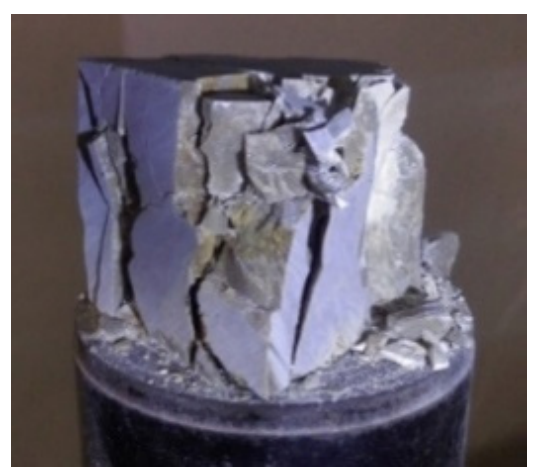

Fig. 10. View of after-study samples in the universal testing machine $[10]$

\section{Assessment of the impact of the rock mass on the support of the heading}

In case of the analyzed adit, the amount of stress in the surrounding rock mass was determined assuming a variation in its cross-sectional dimensions and changes in the strength and deformation properties of the rock mass, as well as the stress resulting from the depth of the excavation, taking into account natural and mining factors.

The impact of the rock mass on the support of the analyzed heading was assessed while having taken the following assumptions:

- due to the location, it was assumed that the excavation is located at a depth of about $24 \mathrm{~m}$,

- the analyzed heading is protected with a support of variable dimensions,

- the calculations take into account the variability of stress arising from varying dimensions of the exposed roof and the conditions taking into account the stress concentration zones,

- the load of the support and the forced displacement of the heading contour were determined without taking into account the effect of mining activities, e.g. exploitation and rock mass tremors.

Taking into account the above assumptions to distinguish the models of stress and deformation forces in the rock mass in the vicinity of each of the analyzed sections of the excavation, calculations of the load were carried out at the points located along the heading, according to the rules specified by PN-G-05020:1997. 
The results of the calculations are presented in Table 1.

Table 1. Examples of the results of calculations of the adit support stress (cross-sections according to Fig. 4)[10]

\begin{tabular}{|c|c|c|c|c|c|}
\cline { 2 - 6 } \multicolumn{1}{c|}{} & $\begin{array}{c}\text { C-S } \\
\text { A-A' }\end{array}$ & $\begin{array}{c}\text { C-S } \\
\text { B-B' }\end{array}$ & $\begin{array}{c}\text { C-S } \\
\text { C-C' }\end{array}$ & $\begin{array}{c}\text { C-S } \\
\text { D-D' }\end{array}$ & $\begin{array}{c}\text { C-S } \\
\text { E-E' }\end{array}$ \\
\hline$q_{\mathrm{N} 2}[\mathrm{kPa}]$ & 25 & 48 & 21 & 22 & 65 \\
\hline$q_{\mathrm{Nx} 1}[\mathrm{kPa}]$ & 0 & 27 & 0 & 0 & 37 \\
\hline$q_{\mathrm{N} \times 2}[\mathrm{kPa}]$ & 0 & 61 & 0 & 0 & 72 \\
\hline
\end{tabular}

\section{Assessment of capacity of the support structure, taking into consideration its current technical condition}

While shaping models of the support structure for each section of the heading, it was assumed that:

- strength parameters of the materials of which the structure of the heading was made correspond to the results of the conducted studies,

- because of the age of the heading, it was assumed that cement and lime mortar of class M1 was used to connect the bricks of the support,

- the calculation was based on the assumption that the average thickness of the wall of the support tunnel is $0.3 \mathrm{~m}$,

- strength parameters and deformation of the wall in the structure of the support correspond to the results of the conducted studies,

- the calculations were made assuming the least favorable load conditions,

- the method and the amount of the load on the analyzed segments of the support were adopted in accordance with paragraph 4.

A simplified model of the heading with a highlighted load diagram is shown in Figure 11.

a)

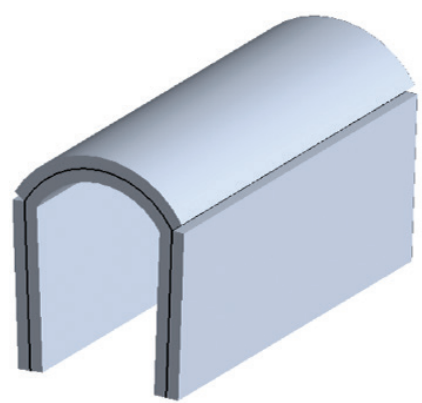

b)

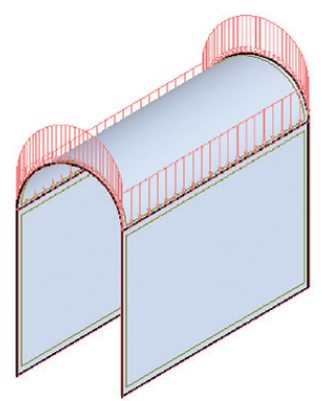

c)

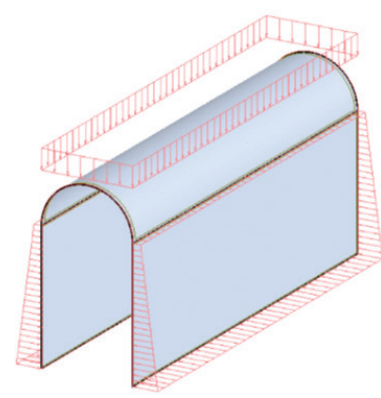

Fig. 11. A simplified heading stone support model with distinguished load schema: a) numerical projection of a fragment of the existing support on the heading section, b) schema of adopted support load in sections made in rocks, c) schema of adopted support load in sections made in quaternary sediments 
Having developed those numerical models, the internal forces and the reduced stresses in the elements of the support were calculated with the use of the Autodesk Robot Structural Analysis Professional 2016 software package.

On the basis of the results of numerical modelling, the degree of security of 90 individual support segments of the analyzed heading was assessed. For this purpose, an indicator of exhaustion of structural load sections was used as expressed with a rate of exhaustion of its cross-section. The structure is considered to be safe if the ratio reaches a value of less than 1 . The method of load calculation of the support used in this case and the simplified static diagram indicate that the structural elements of the support are mainly subject to compressive stress (Fig. 12 and 13).
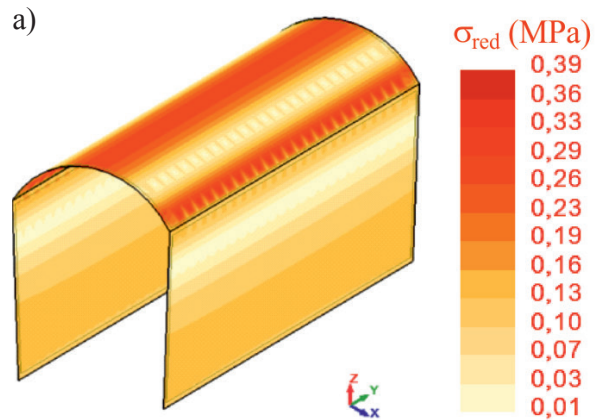

c)
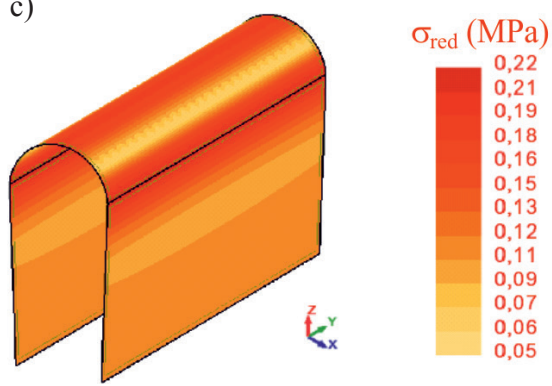

b)

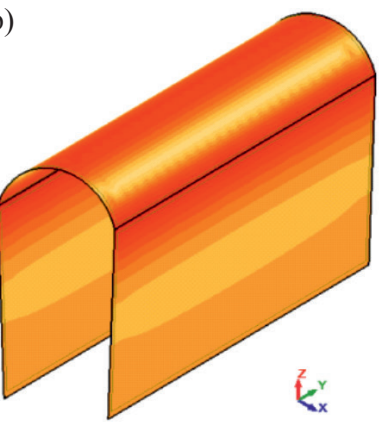

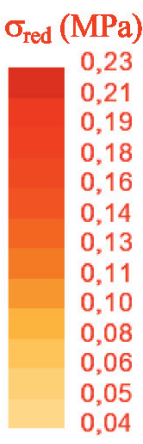

Fig. 12. Shaping of tension values reduced in support elements in heading sections made in rocks: a) in cross-section A-A' (Fig. 4), b) in cross-section B-B' (Fig. 4), c) in cross-section D-D' (Fig. 4)

On the basis of the results of numerical modeling and the analysis of the technical condition of individual support segments of the analyzed heading, it was assumed that the degree of exhaustion of the most stressed cross-section amounts to:

- in case of the sections made in hard rocks:

$\begin{array}{lll}\triangleright \text { for A-A' cross-section } & k=0.12 \\ \triangleright \text { for B-B' cross-section } & k=0.07 \\ \triangleright \text { for D-D' cross-section } & k=0.07\end{array}$

- in case of the sections made in quaternary sediments:

$\triangleright$ for B-B' cross-section $\quad k=0.47$

$\triangleright$ for E-E' cross-section $\quad k=0.64$ 
a)

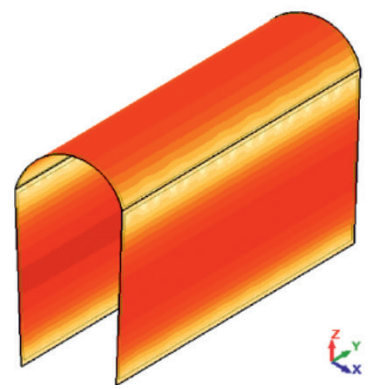

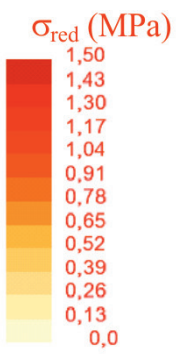

b)

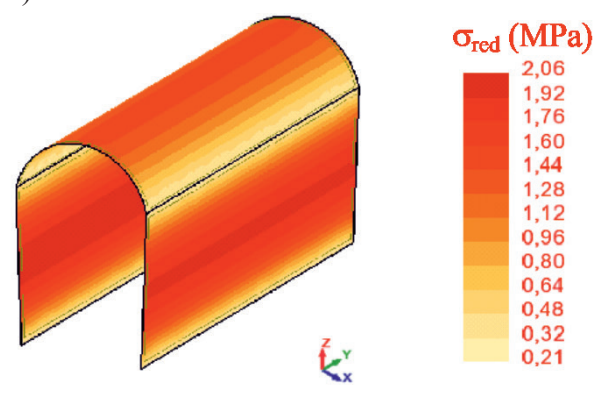

Fig. 13. Shaping of tension values reduced in support elements in heading sections made in quaternary sediments: a) in cross-section B-B' (Fig. 4.1), b) in cross-section E-E' Ffig. 4.1)

In summary, the calculation concluded that the assumptions made for the support meet the criterion of safety in view of the load-bearing capacity of the structure. The values of coefficients calculated for the sections of the heading made in the hard rocks leave a much higher safety margin than those calculated for hollow sections in the quaternary sediments.

\section{Factors influencing the course of natural deterioration of the end section of the "Fryderyk" ("Kościuszko") adit}

It is assumed that the static load of the support due to overburden rocks (the weight of the rocks in the zone stressing the support of the heading) and the hydrostatic pressure of water in the subsurface have the primary impact on the supports located at a small depth. In case of the analyzed "Fryderyk" (Kościuszko) adit sections in the area of the Miners' Gate, the main external factors may include:

- construction works in the area of the adit,

- changes in vegetation on the surface,

- variable water flow in the tunnel and its surroundings,

- the impact of weather conditions.

However, having assumed a shallow retention of the heading, one must reckon with the possibility of additional impacts indirectly related to the rock mass. Those interactions include:

- geostatic increase in the stress caused by water conditions in the soil layer,

- geostatic increase in the load due to other elements stressing surface directly in the vicinity of the heading,

- the occurrence of dynamic ground vibration caused by seismic activity, mining or transport.

There are no buildings along the analyzed section of the adit; the area is covered with grass, shrubs and trees. For a long time, the surface of the adit was used as a grassy meadow. In recent years, the meadow turned into a forest, which means that plants growing over the area have larger root structures that may penetrate the support (especially in the joints of the wall made of a material which is easy to chip), causing its degradation. 
One of the decisive factors influencing the conditions of maintaining the stability of the adit may be construction works, for example, of a well situated virtually adjacent to the tunnel. These works led to a clear interference in the environment of the adit, through the execution of a new, vertical subsurface excavation, which had an impact on the adit - a sided unveiling of the support affecting the previously established balance in the soil. The stability of the support tunnel may also be influenced by weather conditions, especially precipitation and its impact on changes in the properties of the soil and load conditions of the support. An increased inflow of the soil as a result of precipitation and a runoff because of the drainage of the area due to the existence of the adit may also facilitate the process of suffosion, which may result in loosening of the ground. Due to the shallow depth of the location and the direct connection of the tunnel to the surface, one cannot also exclude the process of cyclic freezing and thawing of the land and of the support.

\section{Assessment of risk to the surface and its infrastructure in case the support of the adit loses its stability}

The fact that the heading has a shallow location in its initial section, as measured from the outlet tunnel, had a decisive influence on the increased risk of the possibility of discontinuous deformations on the surface. The possibility of such a threat was confirmed during fieldwork in a form of sinkholes. The first appeared in 1962, and the second in 2008. After a visit to the site, it was found that both sinkholes appeared as results of breakages in roof sections of the support. The sinkhole of 1962 is now partially buried and the support tunnel in this section is restored; however, the sinkhole from 2008 is only protected by wooden cabinet anchors and the area around the sinkhole is fenced and marked as a danger zone.

It can be assumed that the sinkholes generate voids located at a depth of up to $100 \mathrm{~m}$. Those voids are often associated with tunnel headings that were improperly eliminated or left in its natural state [6].

For the purpose of estimating the probability of sinkholes as a result of loss of stability of the inlet section of the tunnel support, the Chudek-Olaszowski method was used [3]. The analyzed section of the tunnel runs almost horizontally at a depth of 0 to $25 \mathrm{~m}$ counting from the roof of the heading.

The heading was dug in the layers of sand, loam or clay, as well in the roof section of the dolomite layer, which is residual beneath the overburden. Taking into account the above information and including the depth of the heading, it should be explicitly stated that a possible collapse in the area would include the loose layer of overburden.

Thus, in the light of the Chudek-Olaszowski method, a loss of stability of the support of the heading would, beyond any doubt, result in an appearance of a sinkhole on the surface. The sinkhole would appear in the area where the loose overburden is located. Therefore, the area should be classified as D category. 


\section{Assessment of the safety of the support in the analyzed section of the adit}

Underground headings used over a long time, especially when the access to them has been cut off for a significant time, usually have supports with a large and often very uneven degree of technical wear. In this situation, load-bearing capacity of the support can be treated as a random variable with a certain probability distribution or a certain range of variation. Similarly, the state of the rock mass in the vicinity of the heading with a long-term existence is progressive and the degradation is often very different in each section. In this case, the parameters describing the current state of the rock mass can also be treated as random variables with a certain probability distribution or range of variation. Assuming that the parameters determining the stability of the historic underground headings are random variables, it is advisable to use a probabilistic method to analyze the stability of the excavation.

In theory of reliability and security of structures based on a probabilistic analysis, the measure of reliability may be the likelihood of loss of stability. The size of the probability of impact is influenced by the so-called safety margin (the difference in the capacity of the structure and its load) and the variance of basic data to determine the stability of the heading.

The evaluation of construction safety is a solution to a two-stage probabilistic approach based on the assumption that the failure condition can be written as:

where:

$$
Z_{0}=P_{0}-q_{0} \geq 0
$$

$Z_{0}$ - safety margin,

$P_{0}$ - capacity of the support,

$q_{0}-$ load of the support.

The Cornell's reliability index $(t)$ is assumed to be a measure of safety:

$$
t=\frac{\bar{P}_{0}-\bar{q}_{0}}{\sqrt{s_{P_{0}}^{2}+s_{q_{0}}^{2}}},
$$

where:

$s_{P 0}, s_{q 0}-$ standard deviation of capacity and load of the support.

The value of the cumulative distribution coefficient reliability $p(t)$ is the probability of the safety of the structure, while the value $[1-p(t)]$ is the probability of failure of the structure (loss of stability of the support).

In this method, the conditions of reliability and safety are used, such as:

where:

$$
p \leq p_{a}
$$

$p$ - probability of the loss of stability,

$p_{a}$ - accepted level of probability of the loss of stability.

One of three classes of conditions for maintaining stability of a heading can be distinguished on the basis of the relationship between the behavior of the headings and the probability of the loss of their stability, namely: 
Class I $-p \leq 0.10-$ safe conditions,

Class II $-0.10<p \leq 0.35$ - sufficient conditions (acceptable),

Class III $-p>0.35$ - dangerous conditions (unacceptable).

In order to safely meet its technological requirements, a corridor heading should be classified as Class I. Conditionally, it is permitted to qualify for Class II, but in this case its supervisor should be ready to carry out repair works or limit the scope of its use.

Using the results of the measurements of the actual thickness of the support, the strength of its bricks and their statistical analysis, the calculations of the current capacity of the support were carried out.

Having considered the overburden of the support and its load-bearing capacity as random variables with normal Gauss distribution of probability, the probability of the loss of stability along the support tunnel was determined. The calculations were made taking into account the variability of the load and the capacity of the support along the tunnel, therefore dividing it into sections characteristic in terms of the support capacity and the size of the projected load. The results of the calculations are presented in Fig. 14.

In reference to the calculations carried out above the classification, it can be said that the following tunnel sections can be distinguished along the length of the tunnel:

Class III (dangerous conditions - unacceptable) - 0-45 m from the Miners' Gate,

Class II (sufficient conditions - acceptable) - 45-118 m; 126-143 m; 156-158 m; 632-739 m; 761-788 m; 969-979 $\mathrm{m}$ and 1149-1163 m from the Miners' Gate,

Class I (safe conditions) - 118-126 m; 143-156 m; 158-632 m; 739-761 m; 788-969 m; 979-1149 $\mathrm{m}$ and $1163-1268 \mathrm{~m}$ from the Miners' Gate.

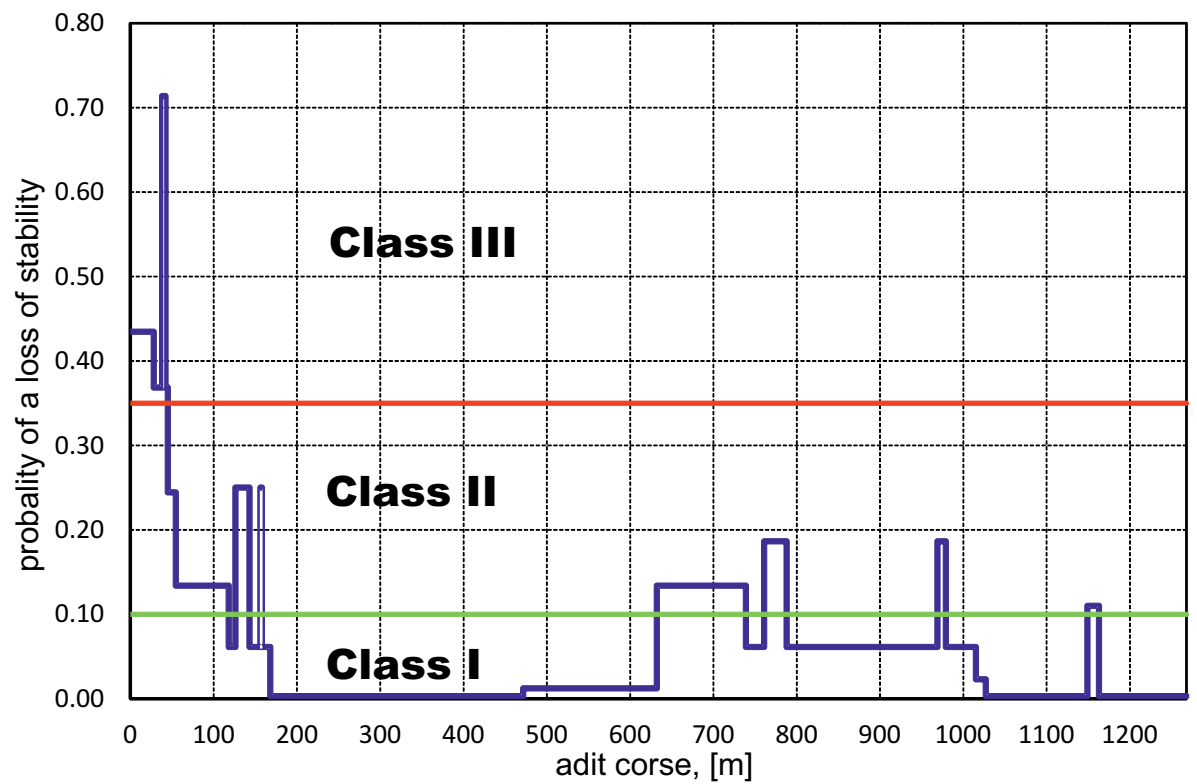

Fig. 14. Graph of the adits stability loss probability at its length 


\section{Summary}

Summarizing the results of the study, it can be concluded that the support tunnel "Fryderyk" (Kościuszko) in its final section to the outlet in Ptakowice shows a varying degree of technical wear. The conditions affecting its state are mainly the following:

- long life of the heading,

- low quality support (mortar quality, accuracy, performance, etc.)

- the adverse impact of the environmental factors - exposure to water, vegetation and other living organisms, etc.,

- lack of maintenance and repair of the support.

On the basis on the conducted field research and performed calculations of the static strength of the support and the size of the load, while taking into account the impact of natural factors on the process of degradation of the support tunnel, the scope of necessary actions required in order to halt the natural degradation of the final section of "Fryderyk" (Kościuszko) was defined. These measures are grouped into four blocks of problems:

- practical measures needed to secure the endangered tunnel sections,

- research and technical expertise,

- design works (technical and technological projects)

- organizational activities.

Practical measures needed to secure the endangered tunnel sections:

- immediately take corrective action and protect the tunnel sections at risk of losing stability, observations of the behavior of the tunnel support and maintenance works should be carried out in the other sections,

- existing sinkholes should be secured before their further development advances.

Research and technical expertise should aim to:

- prepare updated geological documentation for the surroundings of the adit

- prepare basic geological and mining documentation,

- commence studies on the structure and properties of the rock mass,

- determine the impacts and environmental risks.

The basic design works should include:

- a utilization project for "Fryderyk" (Kościuszko) adit in terms of its further use.

- a technical design of extensive reconstruction of the final section of "Fryderyk" (Kościuszko) adit within the area of about $50 \mathrm{~m}$ from its inlet.

- a technological plan for the repair of the support and securing the adit.

- detailed documentation specifying the method and technology of repair of the damaged support sections.

The organizational measures should focus on:

- determination of the administrator of the adit,

- determination of the legal grounds for the functioning of the adit,

- determination of the boundaries of the area and the mining land,

- solution of the problem of land ownership. 


\section{References}

[1] Chudek M., Budownictwo podziemne cz. I. Obudowa wyrobisk korytarzowych i komorowych, „Śląsk”, Katowice 1987.

[2] Chudek M., Duży S., Kleta H., Kłeczek Z., Stoiński K., Zorychta A., Zasady doboru i projektowania obudowy wyrobisk korytarzowych i ich połaczeń w zakładach górniczych wydobywajacych węgiel kamienny, KGBPiOP Pol. Śl., Gliwice-Kraków-Katowice 2000.

[3] Chudek M., Janusz W., Zych J., Studium dotyczace rozpoznania tworzenia się i prognozowania deformacji nieciagłych pod wptywem podziemnej eksploatacji złóż, Zeszyty Naukowe Politechniki Śląskiej, Górnictwo, No. 141, Gliwice 1988.

[4] Duży S., Studium niezawodności konstrukcji obudowy i stateczności wyrobisk korytarzowych $w$ kopalniach węgla kamiennego z uwzględnieniem niepewności informacji, Zeszyty Naukowe Politechniko Sląskiej, Górnictwo, No. 277, Gliwice 2007.

[5] Kerber B., Charakterystyka złóż w rejonie tarnogórskim. Charakterystyka rud cynku i ołowiu na obszarze śląsko-krakowskim, Prace, Instytut Geologiczny, Wyd. Geologiczne, Warszawa 1977.

[6] Strzałkowski P., Wpływ płytkiej eksploatacji górniczej na zagrożenie powierzchni terenu deformacjami nieciagtymi, Zeszyty Naukowe Politechniko Sląskiej, Górnictwo, No. 246, Gliwice 2000.

[7] Duży S., Probabilistyczna analiza stateczności budowli podziemnych, Przegląd Górniczy, No. 4/2004.

[8] Duży S., Ocena bezpieczeństwa konstrukcji wyrobisk korytarzowych w kopalniach węgla kamiennego z uwzględnieniem zmienności warunków naturalnych i górniczych, Bezpieczeństwo Pracy i Ochrona Środowiska w Górnictwie, 2005, No. 6(130).

[9] Duży S., Preidl W., Bączek G., Dyduch Ł., Pawlas Ł., Ocena niezawodności i bezpieczeństwa konstrukcji obudowy kamiennej wyrobisk Kopalni Ćwiczebnej Muzeum Miejskiego „Sztygarka” w Dąbrowie Górniczej poddanych niekorzystnemu oddziaływaniu środowiska, Górnictwo i Geologia, 2012, 47-58.

[10] Duży S., Dyduch G., Preidl W., Stacha G., Czempas A., Utko S., Opracowanie stużące podjęciu działań dla zahamowania naturalnej degradacji końcowego odcinka historycznej sztolni „Fryderyk” („Kościuszko”) w Tarnowskich Górach, z wylotem znajdującym się na terenie Ptakowic gm. Zbrosławice, NB-189/RG-4/2016, Gliwice 2016 (not published).

[11] Zadanie dotyczace rozpoznania możliwości i metod zabezpieczenia zapadliska przy Bramie Gwarków oraz rozpoznanie możliwości i metod zabezpieczenia wejścia do nieczynnego wyrobiska górniczego będacego miejscem wlotu nietoperzy przed osuwającymi się odłamkami skalnymi w Kamieniołomie Bobrowniki, Praca GIG, Katowice 2015.

[12] Kraatz L., Karte des Oberschlesischen Erzbergbaues heraus gegeben von dem Königlichen Oberbergamt zu Breslau in den Jahren 1911-1912, Lith. Anst., Berlin 1912. 